\title{
STATE OF THE MANAGEMENT OF MUNICIPAL WASTE IN THE CONTEXT OF REVERSE LOGISTICS
}

\author{
${ }^{1}$ Mária TROŠANOVÁ, ${ }^{2}$ Ivona ŠKULTÉTYOVÁ, ${ }^{3}$ Dušan RUSNÁK \\ 1,2,3 Department of Sanitary and Environmental Engineering, Slovak University of Technology \\ Radlinského 11, 81005 Bratislava, Slovakia, e-mail: ${ }^{1}$ maria.trosanova@stuba.sk \\ 2ivona.skultetyova@stuba.sk, ${ }^{3}$ dusan_rusnak@stuba.sk
}

Received 5 January 2018; accepted 13 April 2018

\begin{abstract}
Reverse logistics is one of the main processes for the realization of the circular economy. The aim is ensuring the material recovery of waste through its re-use or recycling in a way that is environmentally friendly and economically interesting. The municipality is responsible for the waste management of municipal waste streams. This paper deals with an efficiency of municipal expenditures dedicated to waste management from the expenditures allocated for environmental protection and the achievement of waste management objectives.
\end{abstract}

Keywords: Municipal waste, Efficiency, Recycling

\section{Introduction}

Although the definition of municipal waste varies around the world, some common characteristics can be established in the definitions of Municipal Solid Waste (MSW) [1]:

- waste is from private households;

- includes similar waste from small enterprises, offices and other institutions;

- waste is that is collected through the municipal waste collection system.

The waste catalogue and hazardous waste list are used for the classification of all wastes and hazardous wastes under the catalogue number. The municipal waste is under number 20 in Slovakia and in the EU [2], [3].

The municipal government is responsible for the implementation of municipal waste programs and facilities within their jurisdiction and it makes a decision if the 
municipality is directly involved in providing MSW services or if they are licensing companies to provide these services [4]. Municipal waste management involves establishment of an efficient system for the collection, sorting, recovery, recycling and disposal of municipal waste. However, waste management is a very special activity as its purchase is compulsory and a waste management fee is levied on users of the service [5]. The system effectiveness can be evaluated from many perspectives. The most important is the economic aspect (efficiency of selected municipal waste costs) and the ecological aspect (achievement of waste management objectives in municipal waste). The economic aspect can be evaluated through some of analysis as Cost-Minimization Analysis (CMA), Cost-Benefit Analysis (CBA), Cost-Effectiveness Analysis (CEA), or Cost-Utility Analysis (CUA), depending on the characteristics of the monitored problem [6]. The environmental aspect of municipal waste area can be assessed primarily based on objective for increasing the preparation for reuse and recycling of household waste such as paper, metal, plastics and glass according to the waste directive [7].

Municipality should strive to achieve the balance between economic and environmental aspects. Increasing collecting and sorting of separate fraction as paper, plastic, glass and metal can reduce municipal waste fees. The mixed municipal waste still contains an enormous amount of separately collected fraction and bio waste, which can be recycled or recovered. In this situation, the concept of reverse logistics can help the municipality. The main activities of reverse logistics are the collection, sorting, dismantling and processing of used products, components, by-products, surplus stocks and packaging material where the main purpose is to ensure their new use or material recovery in a way that is environmentally friendly and economically interesting. It is also about management waste streams that do not represent an economic value and are intended for disposal (incineration, landfill) [8]. Reverse logistics is also an important part of the circular economy.

\section{Methodology}

Methodology in this paper included four main steps. In the first step was analyzed a percentage ratio of the current situation of environmental protection expenditure according to Classification of Environmental Protection Activities (CEPA) (Table I) in the EU, Slovakia and Bratislava [9].

The waste management is one of the key elements of classification CEPA and therefore environmental protection expenditure obtained on the basis of available Eurostat data from 2013 and available data from Statistical Office (SO) of the Slovak Republic (SR) were calculated per capita [10]-[15]. Subsequently the data were compared in the EU and Slovakia. Waste management activities covering the entire waste management sector.

The expenditure on environmental protection in Bratislava were calculated of available data from Statistical Office of the SR [10]-[14], the Final Account of the capital city of the Slovak Republic Bratislava for the year 2015 [16] and data about amounts of Municipal Waste (MW) generated, which was provided by Magistrate of the capital city of Slovak Republic Bratislava. Waste management activities covering only municipal waste management for which the municipality is responsible. 
Table I

Classification of environmental protection activities and expenditure

\begin{tabular}{|l|l|}
\hline CEPA 1 & $\begin{array}{l}\text { Protection of ambient air and climate } \\
\text { CEPA 2 }\end{array}$ \\
CEPA 3 & $\begin{array}{l}\text { Waste management involving prevention of pollution through in-process } \\
\text { modifications, collection and transport, treatment and disposal of } \\
\text { hazardous waste, treatment and disposal of non-hazardous waste, } \\
\text { measurement, control, laboratories and the like and other activities }\end{array}$ \\
CEPA 4 & $\begin{array}{l}\text { Protection and remediation of soil, groundwater and surface water } \\
\text { Noise and vibration abatement (excluding workplace protection) }\end{array}$ \\
CEPA 5 & Protection of biodiversity and landscapes \\
CEPA 6 & Protection against radiation (excluding external safety) \\
CEPA 8 & Environmental research and development \\
CEPA 9 & Other environmental protection activities \\
\hline
\end{tabular}

Source: On the basis of Eurostat [9]

The second step was focused on choice of suitable cost-output evaluation method of the current research. On base of acquired data as expenditure of waste management [17], municipal waste generated by 17 City District of Bratislava in years 2011-2015, defined territorial units (Table II) compared with the outputs of the individual analysis (monetary units at CBA, many output units per cost unit realized at CEA or the benefits flowing from the CUA project), was selected (CEA).

Table II

Territorial units

\begin{tabular}{|c|c|c|c|}
\hline District & City District of Bratislava & District & City District of Bratislava \\
\hline Bratislava I & Staré Mesto & \multirow[b]{2}{*}{ Bratislava III } & Nové Mesto \\
\hline \multirow[t]{2}{*}{ Bratislava II } & $\begin{array}{l}\text { Podunajské Biskupice } \\
\text { Ružinov }\end{array}$ & & $\begin{array}{l}\text { Rača } \\
\text { Vajnory }\end{array}$ \\
\hline & Vrakuňa & \multirow{3}{*}{ Bratislava V } & Čunovo \\
\hline \multirow{2}{*}{ Bratislava IV } & $\begin{array}{l}\text { Devín } \\
\text { Karlova Ves } \\
\text { Devínska Nová Ves }\end{array}$ & & $\begin{array}{l}\text { Rusovce } \\
\text { Jarovce } \\
\text { Petržalka }\end{array}$ \\
\hline & $\begin{array}{l}\text { Lamač } \\
\text { Dúbravka } \\
\text { Záhorská Bystrica }\end{array}$ & & \\
\hline
\end{tabular}

Cost-effectiveness analysis was calculated according to Boardman and modified according to methodology of Struk and Soukupova on basic the formula [18], [19]:

$$
C E A=\frac{C}{E} \rightarrow \min
$$

where $C$ is the annual costs; $E$ is the outputs expressed in natural units. 
Calculation of the values for each reviewed unit (City District of Bratislava, Bratislava District) was obtained by using the formula:

$$
C E A_{j}=\frac{C}{E}
$$

where $j=1, \cdots, n$.

Analysis consists in assessment two aspects of effectiveness on samples of 5 districts of Bratislava (17 municipalities), as following:

1) expenditure per capita $E_{1}$;

2) expenditure per tons of municipal waste $E_{2}$.

The third step was evaluated environmental target for MW in 17 City District of Bratislava in years 2011-2015 in line to the Waste Directive. The target of increasing the preparation for re-use and recycling of waste materials from households and similar to waste from households (for instance paper, metal, plastic and glass) at least $50 \%$ by weight until 2020 [6].This target was calculated according to the formula [20]:

$$
\text { Recycling of } M W(\%)=\frac{M W_{\text {recycled }}}{M W_{\text {generated }}} \cdot 100 \text {. }
$$

The analysis consisted of calculating a percentage ratio of the amount of MW generated against MW that was material recycled in 5 Districts of Bratislava.

The final step was consisted from comparing the economic aspects (expenditures per ton of municipal waste) and the environmental objective (achieved recycling of municipal waste) in districts Bratislava $\mathrm{I}-\mathrm{V}$. The result indicates the adequacy of the allocated expenditure in relation to the fulfillment objectives.

\section{Results and discussion}

\section{Analysis of the current situation in the field of environmental protection expenditure}

At EU level, there is a classification of CEPA, which is a functional classification used to classify activities, products, expenditures and other transactions whose primary objective is environmental protection and the statistics that are conducted according to this classification, it can be determined, which areas are more important than others in terms of total spending. The means of the change involve a decision making (complex processes that involve many stakeholders, often with conflicting interests) [21].

As it was mentioned in the methodology, the waste management area is an important part of the expenditure on environmental protection due to allocated expenditures on this area (Fig. 1). In 2013 the EU allocated from the total expenditure $41.16 \%$ on waste management, Slovakia $78.20 \%$. In 2015 Bratislava allocated from the total expenditure $72.25 \%$ on MW management. 


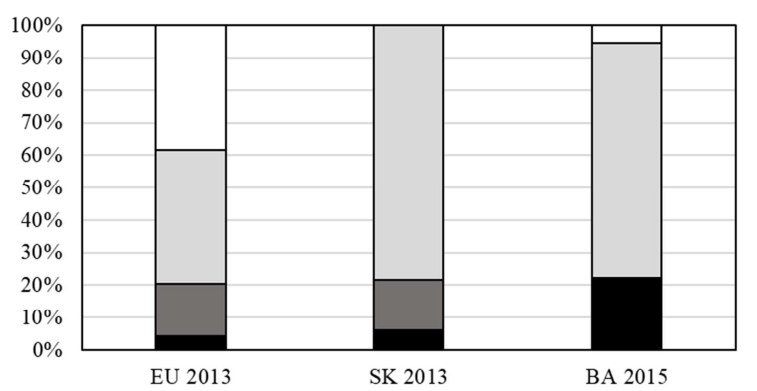

$\square$ Protection and remediation of soil, groundwater and surface water, noise and vibration abatement; protection of biodiversity and landscapes; protection against radiation; env.research and development; other env. protection activities 口Waste management

口Wastewater management

- Protection of ambient air and climate

Fig. 1. Environmental protection expenditures

\section{Cost-effectiveness analysis}

The local fee for municipal waste per capita is the same for each City District of Bratislava and ranges from 32-80 € per capita/year. Prices are, however, dependent on the type of containers, the number of exports or various discounts for defined population groups. In seventeen City Districts of Bratislava associated to the five Districts of Bratislava was population about 423 thousand in 2015. On the territory of monitored districts was generated more than 200 thousand ton of municipal waste, what was $473.5 \mathrm{~kg}$ per capita (Table III). About 25.5 million $€$ was earmarked on waste management. This amount should include all the costs of collection, transport, recovery, disposal and other costs associated with waste management - for example rental of containers, investments in technology, etc. Municipal waste was generated in average $477 \mathrm{~kg}$ per capita in EU and Slovak national average was $329 \mathrm{~kg}$ per capita in 2015.

The efficiency of waste management in individual districts of Bratislava I-V was closely compared in Table $I V$ expenditure per capita $\mathrm{CEAjE}_{1}$ and Table $V$ expenditure per municipal waste ton of $\mathrm{CEAjE}_{2}$. The analysis was evaluated on the basis of increasing costs for the same efficiency.

\section{Expenditure per capita - CEAjE}

Expenditure per capita depends mainly on population. On the other hand, expenditure may be affected by number of enterprises in the district because of more people in the district usually mean more waste generation.

Expenditure per capita in districts of Bratislava I-V ranged between $64.97 €$ and $67.64 €$ for the 5-year period 2011-2015. The data is consistent. District of Bratislava V 
had the lowest expenditure per capita for period 2011-2014. The increase of expenditure in 2015 was due to the decline in the population. In other districts (Bratislava I-IV) the population increased (Table IV).

Table III

Dataset and cost-effectiveness analysis

\begin{tabular}{|c|l|c|c|c|c|c|}
\hline Year & District & $\begin{array}{c}\text { Population } \\
\mathrm{E}_{1}\end{array}$ & $\begin{array}{c}\text { MW generated } \\
{[\mathrm{t}] \mathrm{E}_{2}}\end{array}$ & $\begin{array}{c}\text { MW generated } \\
{[\mathrm{kg} / \text { per capita }]}\end{array}$ & $\begin{array}{c}\text { CEA } \\
\mathrm{j} \mathrm{E}_{1}\end{array}$ & $\begin{array}{c}\text { CEA } \\
\mathrm{j} \mathrm{E}_{2}\end{array}$ \\
\hline \multirow{5}{*}{2011} & Bratislava I & 38788 & 19498.95 & 502.71 & 66.19 & 131.67 \\
& Bratislava II & 109136 & 48666.39 & 445.92 & 67.56 & 151.50 \\
& Bratislava III & 61470 & 26695.30 & 434.28 & 67.64 & 155.74 \\
& Bratislava IV & 92651 & 37976.40 & 409.89 & 67.11 & 163.73 \\
& Bratislava V & 11147 & 48861.45 & 439.61 & 65.43 & 148.83 \\
\hline \multirow{5}{*}{2012} & Bratislava I & 38867 & 18481.14 & 475.50 & 66.06 & 138.93 \\
& Bratislava II & 110158 & 45746.57 & 415.28 & 66.93 & 161.17 \\
& Bratislava III & 62054 & 26996.88 & 435.05 & 67.00 & 154.00 \\
& Bratislava IV & 93386 & 35493.06 & 380.07 & 66.58 & 175.19 \\
& Bratislava V & 111124 & 45630.17 & 410.62 & 65.44 & 159.37 \\
\hline \multirow{5}{*}{2013} & Bratislava I & 38823 & 18374.39 & 473.29 & 66.13 & 139.73 \\
& Bratislava II & 111051 & 50261.04 & 452.59 & 66.39 & 146.70 \\
& Bratislava III & 62546 & 28694.98 & 458.78 & 66.47 & 144.89 \\
& Bratislava IV & 93948 & 38162.41 & 406.21 & 66.19 & 162.94 \\
& Bratislava V & 111021 & 46232.24 & 416.43 & 65.50 & 157.30 \\
\hline \multirow{5}{*}{2014} & Bratislava I & 38988 & 17727.49 & 454.69 & 65.85 & 144.83 \\
& Bratislava II & 112054 & 53872.48 & 480.77 & 65.80 & 136.86 \\
& Bratislava III & 63081 & 26852.75 & 425.69 & 65.91 & 154.83 \\
& Bratislava IV & 94554 & 38869.65 & 411.08 & 65.76 & 159.97 \\
& Bratislava V & 111001 & 47098.08 & 424.30 & 65.51 & 154.41 \\
\hline \multirow{5}{*}{2015} & Bratislava I & 39470 & 19242.15 & 487.51 & 65.05 & 133.43 \\
& Bratislava II & 113201 & 60821.04 & 537.28 & 65.13 & 121.23 \\
& Bratislava III & 63997 & 30788.29 & 481.09 & 64.97 & 135.04 \\
& Bratislava IV & 95376 & 39899.28 & 418.34 & 65.19 & 155.84 \\
& Bratislava V & 110888 & 49499.66 & 446.39 & 65.58 & 146.91 \\
\hline
\end{tabular}

Source: On the basis of data from Statistical Office of the SR [10] - [14] and Magistrate of the capital city of Slovak Republic Bratislava [16].

\section{Expenditure per municipal waste ton - $C E A j E_{2}$}

In general, expenditure per municipal waste can be influenced by the high prices of waste management services, the low-density urban settlement, the low efficiency of collection and transport techniques, the high employment of technical service workers, or the quantity of commodities collected (Table V).

Expenditure per municipal waste ton in districts of Bratislava I-V ranged between $121.23 €$ and $175.19 €$ for the 5-year period 2011-2015. District of Bratislava I had the lowest expenditure per municipal waste ton for the stable production in average $478.74 \mathrm{~kg}$ per capita of waste for period 2011-2015. Bratislava IV had the lowest production of waste (calculation per capita) in average $405.12 \mathrm{~kg}$ per capita, which 
result was the highest expenditure of the municipal waste management in average $163.53 € /$ ton.

Table IV

Expenditure per capita

\begin{tabular}{|c|c|c|c|c|c|c|c|c|}
\hline Year & District & $\begin{array}{c}\text { CEA } \\
\mathrm{jE}_{1}\end{array}$ & Year & District & $\begin{array}{c}\text { CEA } \\
\mathrm{jE}_{1}\end{array}$ & Year & District & $\begin{array}{c}\text { CEA } \\
\mathrm{jE} E_{1}\end{array}$ \\
\hline \multirow{5}{*}{2011} & Bratislava V & 65.43 & \multirow{5}{*}{2013} & Bratislava V & 65.50 & \multirow{5}{*}{2015} & Bratislava III & 64.97 \\
\hline & Bratislava I & 66.19 & & Bratislava I & 66.13 & & Bratislava I & 65.05 \\
\hline & Bratislava IV & 67.11 & & Bratislava IV & 66.19 & & Bratislava II & 65.13 \\
\hline & Bratislava II & 67.56 & & Bratislava II & 66.39 & & Bratislava IV & 65.19 \\
\hline & Bratislava III & 67.64 & & Bratislava III & 66.47 & & Bratislava V & 65.58 \\
\hline \multirow{5}{*}{2012} & Bratislava V & 65.44 & \multirow{5}{*}{2014} & Bratislava V & 65.51 & & & \\
\hline & Bratislava I & 66.06 & & Bratislava IV & 65.76 & & & \\
\hline & Bratislava IV & 66.58 & & Bratislava II & 65.80 & & & \\
\hline & Bratislava II & 66.93 & & Bratislava I & 65.85 & & & \\
\hline & Bratislava III & 67.00 & & Bratislava III & 65.91 & & & \\
\hline
\end{tabular}

Table V

Expenditure per municipal waste ton

\begin{tabular}{|c|c|c|c|c|c|c|c|c|}
\hline Year & District & $\begin{array}{c}\text { CEA } \\
\mathrm{jE}_{2}\end{array}$ & Year & District & $\begin{array}{c}\text { CEA } \\
\mathrm{jE}_{2}\end{array}$ & Year & District & $\begin{array}{c}\text { CEA } \\
\mathrm{jE}_{2}\end{array}$ \\
\hline \multirow{5}{*}{2011} & Bratislava I & 131.67 & \multirow{5}{*}{2013} & Bratislava I & 139.73 & \multirow{5}{*}{2015} & Bratislava II & 121.23 \\
\hline & Bratislava V & 148.83 & & Bratislava III & 144.89 & & Bratislava I & 133.43 \\
\hline & Bratislava II & 151.50 & & Bratislava II & 146.70 & & Bratislava III & 135.04 \\
\hline & Bratislava III & 155.74 & & Bratislava V & 157.30 & & Bratislava V & 146.91 \\
\hline & Bratislava IV & 163.73 & & Bratislava IV & 162.94 & & Bratislava IV & 155.84 \\
\hline \multirow{5}{*}{2012} & Bratislava I & 138.93 & \multirow{5}{*}{2014} & Bratislava II & 136.86 & & & \\
\hline & Bratislava III & 154.00 & & Bratislava I & 144.83 & & & \\
\hline & Bratislava V & 159.37 & & Bratislava V & 154.41 & & & \\
\hline & Bratislava II & 161.17 & & Bratislava III & 154.83 & & & \\
\hline & Bratislava III & 175.19 & & Bratislava IV & 159.97 & & & \\
\hline
\end{tabular}

\section{Environmental aspect}

Environmental aspect (Table VI) was characterized by environmental target on increasing recycling to 2020. Recycling rate of MW was $45 \%$ in EU and $14.9 \%$ in Slovak republic in 2015. In 2015, recycling rate of MW in districts of Bratislava I-V was in average $27 \%$. None of the districts of Bratislava fulfilled the recycling target (the highest recycling rate was $35.91 \%$ in Bratislava II in 2015). The highest percentage of recycling was in the districts of Bratislava I and II over the years 2011-2015. District of Bratislava IV had the lowest percentage of recycling rate, only $15.93 \%$ in average for period 2011-2015. 
Table VI

Environmental target

\begin{tabular}{|c|l|c|c|c|c|}
\hline Year & District & $\begin{array}{c}\text { MW } \\
\text { generated } \\
{[\mathrm{t}] /[\mathrm{kg} / \mathrm{cap}]}\end{array}$ & $\begin{array}{c}\text { MW } \\
\text { recycled } \\
{[\mathrm{t}] /[\mathrm{kg} / \mathrm{cap}]}\end{array}$ & $\begin{array}{c}\text { MW } \\
\text { recycled } \\
{[\%]}\end{array}$ & $\begin{array}{c}\% \text { to } \\
\text { reach } \\
\text { target }\end{array}$ \\
\hline \multirow{5}{*}{2011} & Bratislava I & $19498.95 / 502.71$ & $4113.45 / 106.05$ & 21.10 & 28.90 \\
& Bratislava II & $48666.39 / 445.92$ & $9676.22 / 88.66$ & 19.88 & 30.12 \\
& Bratislava III & $26695.30 / 434.28$ & $3733.46 / 60.74$ & 13.99 & 36.01 \\
& Bratislava IV & $37976.40 / 409.89$ & $3759.83 / 40.58$ & 9.90 & 40.10 \\
& Bratislava V & $48861.45 / 439.61$ & $6322.13 / 56.88$ & 12.94 & 37.06 \\
\hline \multirow{5}{*}{2012} & Bratislava I & $18481.14 / 475.50$ & $3231.96 / 83.15$ & 17.49 & 32.51 \\
& Bratislava II & $45746.57 / 415.28$ & $7589.58 / 68.90$ & 16.59 & 33.41 \\
& Bratislava III & $26996.88 / 435.05$ & $4899.62 / 78.96$ & 18.15 & 31.85 \\
& Bratislava IV & $35493.06 / 380.07$ & $5532.82 / 59.25$ & 15.59 & 34.41 \\
& Bratislava V & $45630.17 / 410.62$ & $7692.79 / 69.23$ & 16.86 & 33.14 \\
\hline \multirow{5}{*}{2013} & Bratislava I & $18374.39 / 473.29$ & $4796.66 / 123.55$ & 26.11 & 23.89 \\
& Bratislava II & $50261.04 / 452.59$ & $12469.43 / 112.29$ & 24.81 & 25.19 \\
& Bratislava III & $28694.98 / 458.78$ & $6473.09 / 103.49$ & 22.56 & 27.44 \\
& Bratislava IV & $38162.41 / 406.21$ & $7459.93 / 79.40$ & 19.55 & 30.45 \\
& Bratislava V & $46232.24 / 416.43$ & $9069.33 / 81.69$ & 19.62 & 30.38 \\
\hline \multirow{5}{*}{2015} & Bratislava I & $17727.49 / 454.69$ & $3483.22 / 89.34$ & 19.65 & 30.35 \\
& Bratislava II & $53872.48 / 480.77$ & $13912.88 / 124.16$ & 25.83 & 24.17 \\
& Bratislava III & $26852.75 / 425.69$ & $4395.59 / 69.68$ & 16.37 & 33.63 \\
& Bratislava IV & $38869.65 / 411.08$ & $6329.83 / 66.94$ & 16.28 & 33.72 \\
& Bratislava V & $47098.08 / 424.30$ & $8093.80 / 72.92$ & 17.18 & 32.82 \\
\hline \multirow{5}{*}{20 Bratislava I } & $19242.15 / 487.51$ & $5108.56 / 129.43$ & 26.55 & 23.45 \\
& Bratislava II & $60821.04 / 537.28$ & $21838.04 / 192.91$ & 35.91 & 14.09 \\
& Bratislava III & $30788.29 / 481.09$ & $9794.01 / 153.04$ & 31.81 & 18.19 \\
& Bratislava IV & $39899.28 / 418.34$ & $7318.06 / 76.73$ & 18.34 & 31.66 \\
& Bratislava V & $49499.66 / 446.39$ & $11875.84 / 107.10$ & 23.99 & 26.01 \\
\hline
\end{tabular}

Source: On the basis of data from Statistical Office of the SR [10] - [14] and data about amounts of MW generated which was provided by Magistrate of the capital city of Slovak Republic Bratislava

The assessment of the economic and environmental aspects

The assessment of the economic and environmental aspects consisted of a comparison of economic efficiency and environmental sustainability. The goal of this comparison was information whether there was an adequate percentage of waste recovery at a given expenditure per ton of waste.

Fig. 2 shows that the percentage of recycling (except for small deviations) is depend on expenditure per ton in individual districts of Bratislava I-V. The highest expenditure on MW ton in compare to achieved recycling target was in district of Bratislava IV. On the opposite site was Bratislava I and Bratislava II. 

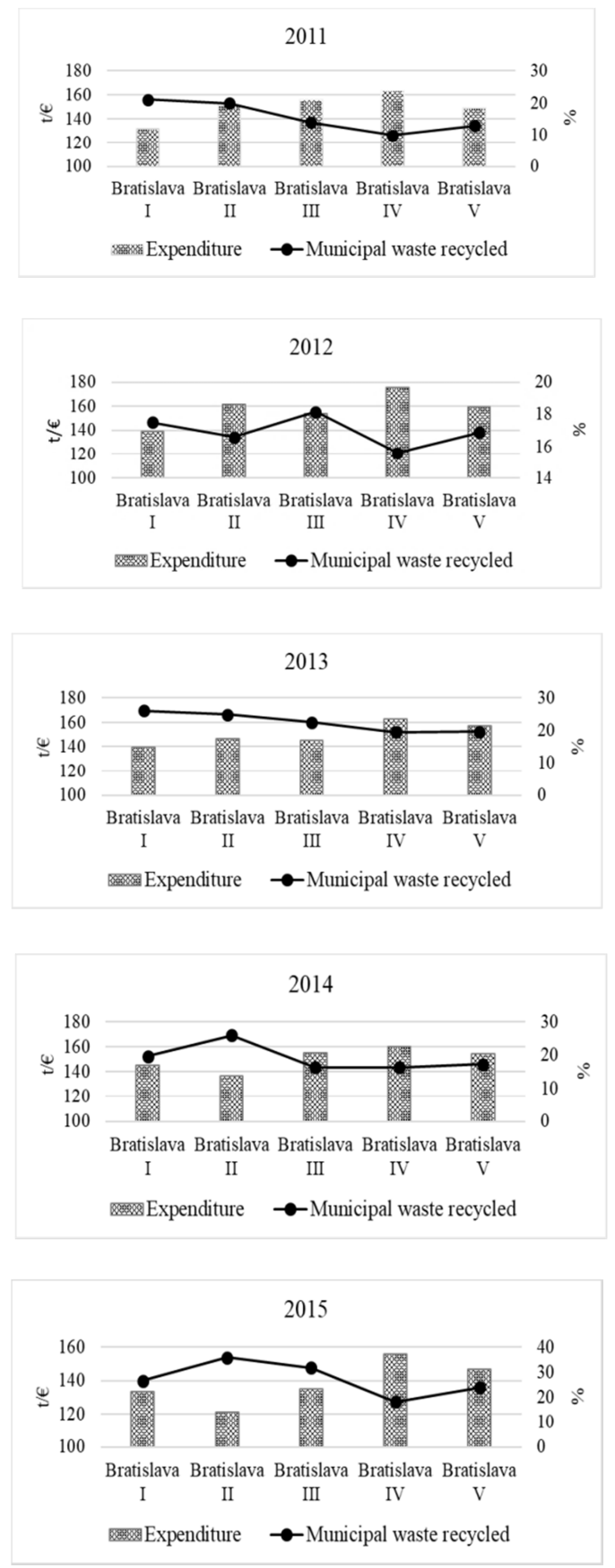

Fig. 2. Comparison of economic and environmental targets 


\section{Conclusion}

An analysis of the current situation shows that expenditure on waste management (included MW) is important part of budgets on environmental protection in EU, state and public administration. Public administration as the management of public affairs represents the public interest hence from the point of view of the inhabitants it means the effective introduction of collection and transportation MW, adequate number of containers and purity in the city at the reasonable price. Bratislava has owned company (OLO Ltd.) responsible for waste collection, transportation, cleanliness in the collection area and other related services.

The paper evaluated the expenditure per capita and expenditure per municipal waste ton in seventeen City Districts of Bratislava associated to the five Districts of Bratislava for MW management in period 2011-2015 by cost-effectiveness analysis (single criterion decision making).

Comparison expenditure per capita in all districts of Bratislava cannot be considered as correct because there is many companies and high employment which generate of higher amounts of MW.

Comparison expenditure per MW ton was considered as more appropriate in all districts of Bratislava. This analysis told how many finances were spent by individual Districts of Bratislava on one ton MW.

In the last part, the percentage of waste recycled at the expenditure per ton MW was analyzed. Dependence was found between these variables. The recycling rates were extremely low what indicates that waste management system needs a major change to reach the environmental objectives. Achieving a higher level of the recycling and recovery of waste contributes to environmental protection, the efficient use of natural resources, increased employment mainly in the waste management sector and the reduction of greenhouse gases.

In general, results of cost-effectiveness analysis provided information about MW management in five districts of Bratislava. Information can be used as a tool for another municipality or for producers of packaging, how the municipality effectively manages expenditures allocated to waste management and the separation packaging waste that producers have funded (financing of separation packaging waste).

In order to obtain a more comprehensive overview of the situation, it is necessary to extend the information about other municipalities in neighboring districts, the information about the recovery and disposal facilities in the local area, the distances to these facilities and density of settlement (for example, the City District of Bratislava Jarovce, Rusovce and Čunovo belonging to District of Bratislava V have the character of a rural settlement).

Municipalities, due to increasing per capita waste generation, have the option of introducing a reverse logistics system that is dedicated to measures leading to the circular economy, which include the reuse, repair, recovery and recycling of material and products, which was hand over at the collection yard as waste, or in cooperation with manufacturers, to ensure the removal of non-functioning household products and to ensure their partial or other reuse and reduce the amount of MW they have to dispose of it. 


\section{Acknowledgements}

This article was created with the support of the Ministry of Education, Science, Research and Sport of the Slovak Republic within the Research and Development Operational Programme for the project 'University Science Park of STU Bratislava', ITMS 26240220084, co-funded by the European Regional Development Fund and by the Slovak Research and Development Agency under the contract No. APVV-0372-12.

\section{References}

[1] Goorhuis M. Developments in collection of municipals Solid waste, In Handbook of Recycling,Sstate-of-the-art for Practitioners, Analysts, and Scientists, Elsevier, 2014, pp. 405-417.

[2] European Union, Commission Decision 2000/532/EC replacing Decision 94/3/EC establishing a list of wastes pursuant to Article 1(a) of Council Directive 75/442/EEC on waste and Council Decision 94/904/EC establishing a list of hazardous waste pursuant to Article 1(4) of Council Directive 91/689/EEC on hazardous waste, 2000, http://eurlex.europa.eu/legal-content/EN/TXT/?uri=CELEX:32000D0532 (last visited 20 June 2017).

[3] Ministry of environment of the SR, Decree of the Slovak Ministry of Environment No. 365/2015 Coll. establishing Catalogue of waste, (in Slovak) 2015.

[4] Piippo S., Saavalainen P., Kaakinen J., Pongrácz E. Strategic waste management planning The organization of municipal solid waste collection in Oulu, Finland. Pollack Periodica, Vol. 10, No. 2, 2015, pp. 145-156.

[5] Kiss T., Drescher L. Effects of the landfill tax on waste management. Pollack Periodica, Vol. 9, No. 1, 2014, pp. 31-42.

[6] Yates B. T. Cost-benefit and cost-effectiveness analyses in evaluation research, International Encyclopedia of the Social \& Behavioral Sciences (2nd ed.), Elsevier, Vol 5, 2015, pp. 55-62.

[7] European Union, Directive 2008/98/EC of the European Parliament and of the Council of 19 November 2008 on waste and repealing certain Directives, 2008, http://eurlex.europa.eu/legal-content/EN/TXT/?uri=CELEX:32008L0098 (last visited 18 October 2017).

[8] Škapa R. Revese logistics, Masaryk University, Brno, (in Czech) Vol. 1, 2005. pp. 20-22.

[9] Eurostat, RAMON - Reference And Management Of Nomenclatures, 2000, http://ec.europa.eu/eurostat/ramon/nomenclatures/index.cfm?TargetUrl=LST_NOM_DTL $\&$ StrNom=CEPA_2000\&StrLanguageCode $=E N \& I n t P c K e y=\&$ StrLayoutCode $=$ HIERARC HIC\&CFID=1595380\&CFTOKEN=15b2f66fb7b279e8-4E1704F0-FEE6-0A3D-9ED1A E1678 A45850\&jsessionid=f900b645764e28582e3c (last visited 21 October 2017).

[10] Statistical Office of the Slovak Republic, Regional Statistical Yearbook of Slovakia 2012, Bratislava, Statistical Office of the SR, 2013, p. 21, ISBN 978-80-8121-226-0.

[11] Statistical Office of the Slovak Republic, Regional Statistical Yearbook of Slovakia 2013, Bratislava, Statistical Office of the SR, 2014, p. 428, ISBN 978-80-8121-301-4.

[12] Statistical Office of the Slovak Republic, Regional statistical yearbook of Slovakia 2014, Bratislava, Statistical Office of the SR, 2015, p. 416, ISBN 978-80-8121-437-0.

[13] Statistical Office of the Slovak Republic, Regional Statistical Yearbook of Slovakia 2015, Bratislava, Statistical Office of the SR, 2016, p. 450, ISBN 978-80-8121-527-8.

[14] Statistical Office of the Slovak Republic, Regional Statistical Yearbook of Slovakia 2016, Bratislava, Statistical Office of the SR, 2017, p. 451, ISBN 978-80-8121-552-0. 
[15] Eurostat, Environmental protection expenditure - million euro and million units of national currency, http://appsso.eurostat.ec.europa.eu/nui/show.do?dataset=env_ac_exp1r2\&lang $=$ en, (last visited 16 October 2017).

[16] Magistrate of the capital city of Slovak Republic Bratislava, The final account of the capital city of the Slovak Republic Bratislava for the year 2015 and an evaluation report for 2015, http://bratislava.sk/assets/File.ashx?id_org=700000\&id_dokumenty=11051591, (in Slovak) (last visited 18 October 2017).

[17] City auditor of the capital of the Slovak Republic Bratislava, Report on the results of inspections carried out by the city auditor of the capital city of the Slovak Republic Bratislava, 2017, (in Slovak) http://www.bratislava.sk/assets/File.ashx?id org=700000\&id dokumenty $=11054768$, (last visited 18 October 2017).

[18] Ochrana F. Public procurement: Methods and methodology of effective evaluation and selection, (in Czech) Ekopress, Praha, Vol. 1, 2004.

[19] Struk M., Soukupová J. Efficiency of the current municipal waste management expenditure -methodology approach and its implication, Acta Universitatis Agriculturae et Silviculturae Mendelianae Brunensis, Vol. 59, No. 7, 2011, pp. 379-386.

[20] European Union, Commission Decision 2011/753/EU of 18 November 2011 establishing rules and calculation methods for verifying compliance with the targets set in Article 11(2) of Directive 2008/98/EC of the European Parliament and of the Council, $2011 \mathrm{http}: / /$ eurlex.europa.eu/legal-content/EN/TXT/?uri=CELEX:32011D0753 (last visited 18 October 2017).

[21] Klavenieks K., Dzene K. P., Blumberga D. Optimal strategies for municipal solid waste treatment - environmental and socio-economic criteria assessment, Energy Procedia,. Vol. 128, 2017, pp. 512-519. 